\title{
Sventrin, a New Bromopyrrole Alkaloid from the Caribbean Sponge Agelas sventres
}

\author{
Michael Assmann, ${ }^{\dagger}$ Sven Zea, ${ }^{\ddagger}$ and Matthias Köck*,† \\ Alfred-Wegener-Institut für Polar- und Meeresforschung, Am Handelshafen 12, D-27570 Bremerhaven, Germany, and \\ Departamento de Biología, Universidad Nacional de Colombia, INVEMAR, Santa Marta, Colombia
}

Received J uly 16, 2001

\begin{abstract}
A detailed analysis of the secondary metabolites of a specimen of Agel as sventres was carried out here for the first time. The chemistry of Agelas sponges is dominated by bromopyrrole derivatives. Besides three known bromopyrrole metabolites, a new compound, sventrin (1), was isolated and its structure identified using spectroscopic methods. Sventrin (1) was shown to be a feeding deterrent compound against a common omnivorous reef fish.
\end{abstract}

A series of brominated pyrrole alkaloids have been isolated from a specimen of the sponge Agelas sventres collected off the coast of N orth Cat Cay, Bimini, Bahamas. A. sventres was first described by Lehnert and van Soest in 1996 and before known as Agelas sp. 3 for many years, but the chemistry was unknown. ${ }^{1}$ This is the first report on the chemistry of this Agelas species from the Bahamas. The dichloromethane/methanol extract of this sponge (see Figure 1) resulted in the isolation of the known alkaloids hymenidin (2, $417 \mathrm{mg})$, oroidin (3, $328 \mathrm{mg})$, 4,5-dibromopyrrole-2-carboxylic acid (4, $35 \mathrm{mg}$ ), and a new bromopyrrole-derived alkal oid, sventrin (1, $75 \mathrm{mg}$ ). In this note, we describe the isolation and structural elucidation of this novel bromopyrrole alkaloid $\mathbf{1}$ and the feeding deterrent properties of $\mathbf{1}$ and $\mathbf{2}$ (data of $\mathbf{3}$ and $\mathbf{4}$ are already known) against the omnivorous reef fish Thal assoma bifasciatum.
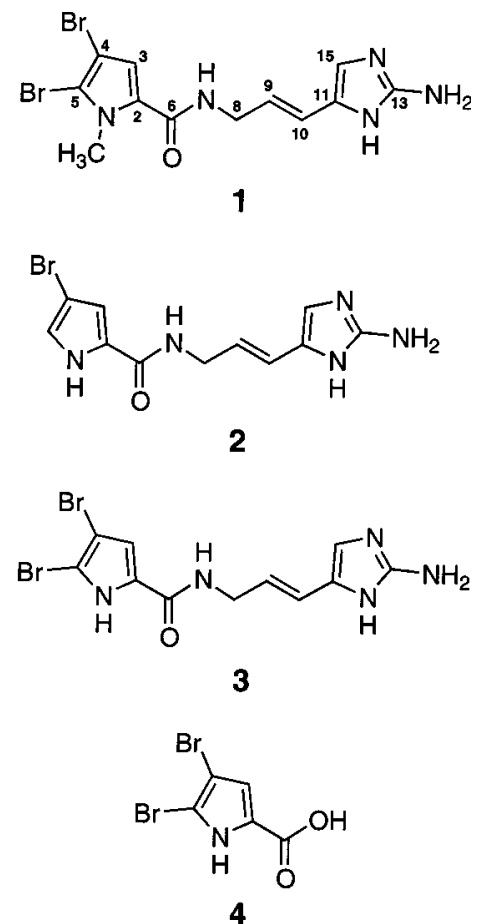

* To whom correspondence should be addressed. Tel: +49-471-4831-1497. Fax: +49-471-4831-1425. E-mail: mkoeck @awi-bremerhaven.de.

† Alfred-Wegener-Institut für Polar- und Meeresforschung, Bremerhaven.

‡ Universidad Nacional de Colombia, INVEMAR, Santa Marta.
The compounds 1-4 were isolated using previously reported methods. ${ }^{2}$ The brominated alkaloids hymenidin (2), oroidin (3), and 4,5-dibromopyrrole-2-carboxylic acid (4) were identified by comparison of their spectroscopic data with those reported in the literature. ${ }^{3}$ The ESI mass spectrum (negative ion mode) of sventrin (1) showed an isotopic cluster at $\mathrm{m} / \mathrm{z} 400,402$, and $404[\mathrm{M}+\mathrm{H}]^{+}$in the ratio 1:2:1, suggesting the presence of two bromine atoms. The molecular formula of $\mathbf{1}$ was established as $\mathrm{C}_{12} \mathrm{H}_{14^{-}}$ $\mathrm{Br}_{2} \mathrm{~N}_{5} \mathrm{O}$ by HRFABMS (m/z 401.9565, $[\mathrm{M}+\mathrm{H}]^{+}, \Delta=0.1$ $\mathrm{mmu}$ ), which is in accordance with the ${ }^{1 \mathrm{H}}$ and ${ }^{13} \mathrm{C} N M \mathrm{R}$ data. The NMR spectra of $\mathbf{1}$ are very similar to those of oroidin (3). The only differences are that $\mathbf{1}$ has one less $\mathrm{NH}$ signal and an additional methyl signal at $3.89 \mathrm{ppm}$. Thesignal at 3.89 ppm was assigned as an N-methyl group. The absence of the pyrrole $\mathrm{NH}$ and the presence of $\mathrm{HMBC}$ correlations from the N-methyl group to $\mathrm{C}-2$ and $\mathrm{C}-5$ established the structure of $\mathbf{1}$ as $\mathrm{N}$ (pyrrole)-methyl oroidin (= sventrin). 1D and 2D NMR data of $\mathbf{1}$ are summarized in the Experimental Section.

Deterrent metabolites appear to be the principal defensive strategy of Caribbean sponges against predatory reef fishes, because in a recent study no evidence was found for structural or nutritional defenses. ${ }^{4}$ Brominated pyrrole derivatives are known to function as feeding deterrents of sponges in the families Axinellidae and Agelasidae. ${ }^{5}$ To investigate the ecological role of the major metabolites of A. sventres, aquarium assays for the feeding deterrency were carried out against a common omnivorous reef fish using previously described methods. $5 c, 6$

Hymenidin (2) was first isolated in 1986, ${ }^{3 c}$ but no reports of testing in the feeding deterrent assay against Thalassoma bifasciatum have yet appeared. Oroidin (3) and 4,5dibromopyrrole-2-carboxylic acid (4) have been tested several times in this assay ${ }^{5 a, c, 7}$ and were therefore not tested again in this investigation. The minimum concentrations for a feeding deterrent activity of these two compounds are $0.7 \mathrm{mg} / \mathrm{mL}$ for 3 and $0.8 \mathrm{mg} / \mathrm{mL}$ for 4 . Sventrin (1) and hymenidin (2) were tested at concentrations of $1,3,5$, and $10 \mathrm{mg} / \mathrm{mL}$ in the aquarium assay (for details see Experimental Section and Supporting I nformation). Hymenidin (2) is not active at $1 \mathrm{mg} / \mathrm{mL}$ (active at 3 $\mathrm{mg} / \mathrm{mL}$ ) and shows therefore a smaller feeding deterrency than oroidin (3). This was expected since it was shown for pyrrole-2-carboxylic acid derivatives that bromination is important for the feeding deterrency. ${ }^{5 \mathrm{c}} \mathrm{Also}, \mathrm{N}$-methylation of the pyrrole nitrogen as in sventrin reduces the feeding 

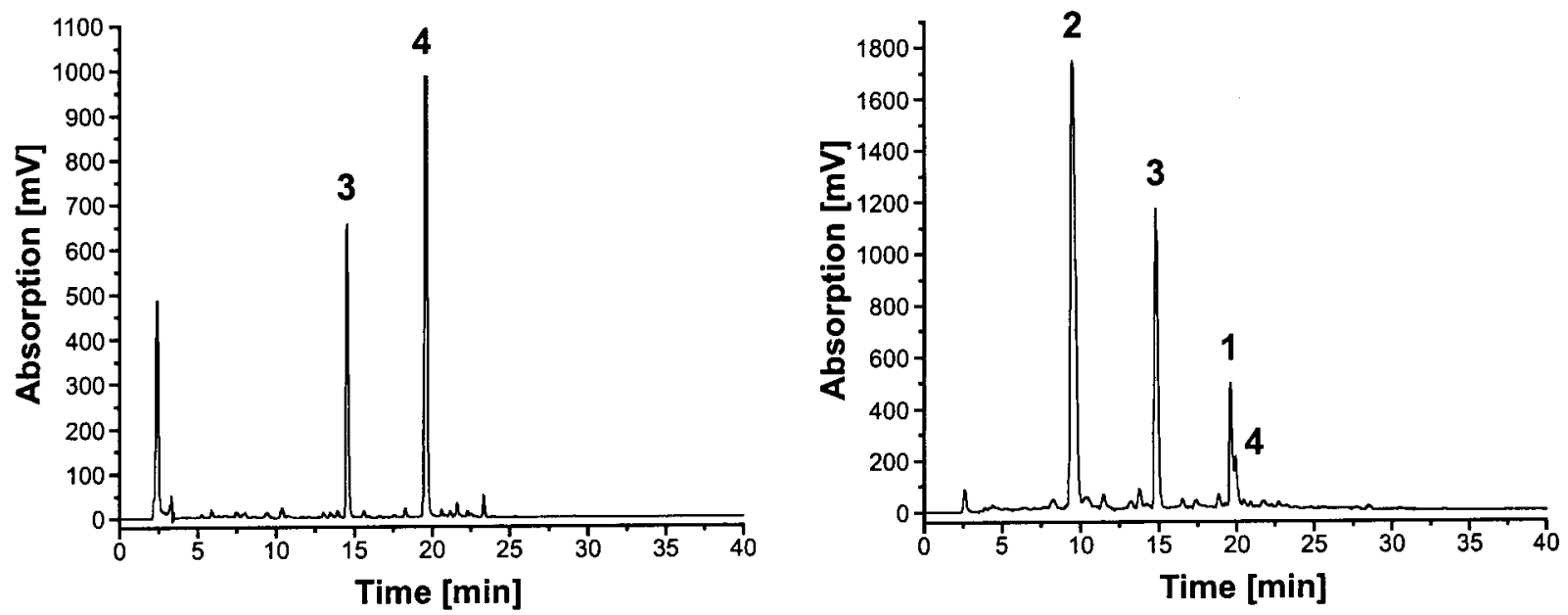

Figure 1. HPLC profiles of the n-butanol phase of Agelas clathrodes (left) and Agel as sventres (right). HPLC conditions, column: Kromasil RP18, $4.6 \times 250 \mathrm{~mm}, 5 \mu \mathrm{m}$; gradient: $20-60 \% \mathrm{MeCN} / \mathrm{H}_{2} \mathrm{O}+0.1 \%$ TFA in $40 \mathrm{~min}$; flow rate: $1 \mathrm{~mL} / \mathrm{min}$, UV detection at $280 \mathrm{~nm}$. The retention times for A. sventres are as follows: hymenidin (2) $t_{R}=9.49 \mathrm{~min}$, oroidin (3) $t_{R}=14.81 \mathrm{~min}$, sventrin (1) $t_{R}=19.61 \mathrm{~min}$, and 4,5-dibromopyrrole-2-carboxylic $\operatorname{acid}(\mathbf{4}) t_{R}=19.96 \mathrm{~min}$.

deterrent activity (for details see Experimental Section). These results and previously obtained results showed that all four compounds deterred feeding of the Caribbean reef fish $\mathrm{T}$. bifasciatum in aquarium assays. However, oroidin (3) is the only component in the tissue of A. sventres at sufficient concentration $(0.9 \mathrm{mg} / \mathrm{mL}$, the minimum concentration required for the feeding deterrency is $0.7 \mathrm{mg} / \mathrm{mL}$ ) to be most likely responsible for the feeding deterrency. The other metabolites 1, 2, and $\mathbf{4}$ were found only in lower tissue concentrations $(0.2,1.1$, and $0.1 \mathrm{mg} / \mathrm{mL}$, respectively). The feeding deterrency is probably effected by all four compounds; however, the mixture has not yet been tested.

The HPLC profile of the crude extract of Agelas sventres differs from that of A. cervicornis, A. clathrodes, A. dispar, and $A$. wiedenmayeri, where the major metabolites are only the "monomeric" building blocks $\mathbf{3}$ and $\mathbf{4}$ (see Figure 1). In none of these Agelas species was either sventrin (1) or hymenidin (2) isolated as a major metabolite. This is further evidence for the distinctiveness of $A$. sventres from A. clathrodes, which traditionally included the former within its variation (see Experimental Section and Supporting I nformation).

\section{Experimental Section}

General Procedures. ${ }^{1 \mathrm{H}}$ NMR and ${ }^{13} \mathrm{C}$ NMR spectra were recorded on Bruker AM250, AMX400, and DRX600 NMR spectrometers. All NMR experiments were measured at $300 \mathrm{~K}$. The DQF $-{ }^{1} \mathrm{H},{ }^{1} \mathrm{H}-\mathrm{COSY},{ }^{1} \mathrm{H},{ }^{13} \mathrm{C}-\mathrm{HSQC},{ }^{1} \mathrm{H},{ }^{13} \mathrm{C}-\mathrm{HMBC}$, ${ }^{1} \mathrm{H},{ }^{15} \mathrm{~N}-\mathrm{HSQC}$, and ${ }^{1} \mathrm{H},{ }^{15} \mathrm{~N}-\mathrm{HMBC}$ experiments were carried out using standard parameters. Mass spectral analysis (HRFABMS) was performed on a J EOL J MS-700 sector-fiel d mass spectrometer with 3-nitrobenzyl alcohol as matrix or using a Fison VG Platform II for ESIMS. HPLC analysis was carried out as previously reported. ${ }^{2} \mathrm{IR}(\mathrm{KBr})$ spectra were recorded on a Perkin-EImer 1600 Series FT-IR spectrometer. UV/Vis spectra were obtained using a Perkin-EImer UV/VIS spectrometer Lambda 16.

Animal Material. The marine sponge Agelas sventres (Lehnert and van Soest, 1996) investigated in this study was collected in August 2000 by scuba diving (18 m depth) at $N$ orth Cat Cay, near Bimini, Bahamas. Voucher specimens are deposited at the Porifera collections of the Zoological Museum Amsterdam, The Netherlands (ZMA POR. 16400), and at the I nstituto de I nvestigaciones Marinas y Costeras, I NVEMAR, Santa Marta, Colombia (I NV-POR 0584). A detailed taxonomic description is given in the Supporting I nformation. The studied material from the Bahamas was kindly compared to the hol otype from J amaica (ZMA POR. 11322) by Dr. Rob W. M. van Soest (Zoological Museum Amsterdam), and the identity confirmed. The species in the Bahamas was originally de scribed within the variation of A. clathrodes (Schmidt, 1870), but it was later discovered that it was a different, undescribed species. ${ }^{9}$ It was dubbed Agelas sp. 3 for many years by Caribbean spongologists until its formal naming and description. ${ }^{1}$ However, its conspecificity with the original A. schmidti (Wilson, 1902) (non A. schmidti sensu Wiedenmayer, $1977^{8}$ and Zea, $1987,{ }^{9}$ which is A. wiedenmayeri Alcolado, $1984^{10}$ ), remains to be determined.

Extraction and I solation. The sample of Agel as sventres was immediately frozen after collection and kept at $-20^{\circ} \mathrm{C}$ until extraction. The freeze-dried sponge sample of $A$. sventres (93.5 g) was chopped into small pieces and extracted at room temperature exhaustively in a $1: 1$ mixture of $\mathrm{CH}_{2} \mathrm{Cl}_{2} / \mathrm{MeOH}$. The orange-col ored crude extract of $\mathrm{A}$. sventres was partitioned between $\mathrm{n}$-hexane $(4 \times 300 \mathrm{~mL})$ and $\mathrm{MeOH}(150 \mathrm{~mL})$. The $\mathrm{MeOH}$ extract was then partitioned between $\mathrm{n}-\mathrm{BuOH}(5 \times 300$ $\mathrm{mL})$ and $\mathrm{H}_{2} \mathrm{O}(300 \mathrm{~mL})$. The resulting $\mathrm{n}-\mathrm{BuOH}(4.32 \mathrm{~g})$ phase from the solvent partitioning scheme was purified by gel permeation chromatography on Sephadex LH-20 (Pharmacia) using $\mathrm{MeOH}$ as mobile phase. Final purification of the isolated compounds was achieved by preparative RP ${ }_{18}$ HPLC (for details, see Supporting I nformation) to afford $\mathbf{l}$ (75 mg, 0.08\% of dry weight), 2 (417 mg, $0.45 \%$ of dry weight), 3 (328 mg, $0.35 \%$ of dry weight), and 4 (35 mg, $0.04 \%$ of dry weight).

Sventrin (1): light yellow powder; UV $(\mathrm{MeOH}) \lambda_{\max }(\log \epsilon)$ 274 (4.27) $\mathrm{nm}$; IR (KBr) $v_{\max } 3334,2360,1696,1541,1506$, $1417,1332,1264,1202,1138,956,800,722 \mathrm{~cm}^{-1} ;{ }^{1} \mathrm{H}$ NMR (DMSO-d $6,250 \mathrm{MHz}) \delta 3.89 \mathrm{~s}, \mathrm{NCH}_{3} ; 3.93 \mathrm{t}$, J $=5.5,5.7 \mathrm{~Hz}$, $\mathrm{H}_{2}-8 ; 6.09, \mathrm{dt}$, J $=5.5,16.1 \mathrm{~Hz}, \mathrm{H}-9 ; 6.23, \mathrm{~d}$, J $=16.1 \mathrm{~Hz}$, $\mathrm{H}-10 ; 6.90, \mathrm{~s}, \mathrm{H}-15 ; 7.06, \mathrm{~s}, \mathrm{H}-3 ; 7.71$, br, $\mathrm{NH}_{2}-16 ; 8.50, \mathrm{t}$, J = $5.7 \mathrm{~Hz}, \mathrm{NH}-7 ; 12.19$, br, NH-14; 12.86, br, NH-12; ${ }^{13} \mathrm{C}$ NMR (DMSO-d 6 , 62.9 MHz) $\delta 35.4, \mathrm{NCH}_{3} ; 39.9, \mathrm{C}-8 ;$ 97.0, C-4; 110.7, C-5; 110.8, C-15; 114.1, C-3; 116.4, C-10; 124.9, C-11; 126.3, C-9; 127.6, C-2; 147.9, C-13; 159.6, C-6; ${ }^{15}$ N NMR (DMSO-d $60.8 \mathrm{MHz}) \delta 59, \mathrm{~N}-16 ; 108, \mathrm{~N}-7 ; 132, \mathrm{~N}-12 ; 135, \mathrm{~N}-14 ; 156$, $\mathrm{N}-1$ (the chemical shifts were calibrated according to the Bruker frequency, which is set to 0 ppm for $\mathrm{NH}_{3}$, the accuracy is about 1 to $2 \mathrm{ppm}$ ); COSY correlations $\mathrm{H}-7 / \mathrm{H}-8, \mathrm{H}-8 / \mathrm{H}-9, \mathrm{H}-9$ / $\mathrm{H}-10 ;{ }^{1} \mathrm{H},{ }^{13} \mathrm{C}-\mathrm{HMBC}$ correlations $\mathrm{H}-1 / \mathrm{C}-2, \mathrm{H}-1 / \mathrm{C}-5, \mathrm{H}-3 / \mathrm{C}-2$, $\mathrm{H}-3 / \mathrm{C}-5, \mathrm{H}-3 / \mathrm{C}-6, \mathrm{H}-7 / \mathrm{C}-6, \mathrm{H}-7 / \mathrm{C}-8, \mathrm{H}-8 / \mathrm{C}-6, \mathrm{H}-8 / \mathrm{C}-9, \mathrm{H}-8 /$ $\mathrm{C}-10, \mathrm{H}-9 / \mathrm{C}-8, \mathrm{H}-9 / \mathrm{C}-11, \mathrm{H}-10 / \mathrm{C}-8, \mathrm{H}-10 / \mathrm{C}-9, \mathrm{H}-10 / \mathrm{C}-11, \mathrm{H}-10 /$ C-15, H-15/C-10, H-15/C-11, H-15/C-13; ${ }^{1} \mathrm{H},{ }^{15} \mathrm{~N}-\mathrm{HMBC}$ correlations $\mathrm{H}-3 / \mathrm{N}-1, \mathrm{H}-8 / \mathrm{N}-7, \mathrm{H}-9 / \mathrm{N}-7, \mathrm{H}-10 / \mathrm{N}-12, \mathrm{H}-15 / \mathrm{N}-12$, H-15/N-14, H-16/N-12, H-16/N-14; HRFABMS m/z 401.9564 $[\mathrm{M}+\mathrm{H}]^{+}$(calcd for $\mathrm{C}_{12} \mathrm{H}_{14}{ }^{79} \mathrm{Br}_{2} \mathrm{~N}_{5} \mathrm{O}, 401.9565$ ). 
Hymenidin (2): light yellow powder; UV (MeOH) $\lambda_{\max }(\mathrm{log}$ $\epsilon) 268(4.25) \mathrm{nm} ;{ }^{1} \mathrm{H}$ NMR and ${ }^{13} \mathrm{C}$ NMR data same as reported in ref 3c; HRFABMS m/z $310.0315[\mathrm{M}+\mathrm{H}]^{+}$, calcd for $\mathrm{C}_{11} \mathrm{H}_{13^{-}}$ ${ }^{79} \mathrm{BrN}_{5} \mathrm{O}, 310.0304$.

Oroidin (3): light yellow powder; UV $(\mathrm{MeOH}) \lambda_{\max }(\log \epsilon)$ 274 (4.35) nm; ${ }^{1} \mathrm{H}$ NMR and ${ }^{13} \mathrm{C}$ NMR data same as reported in refs 3a,b,d; HRFABMS m/z $387.9404[\mathrm{M}+\mathrm{H}]^{+}$, calcd for $\mathrm{C}_{11} \mathrm{H}_{12}{ }^{79} \mathrm{Br}_{2} \mathrm{~N}_{5} \mathrm{O}, 387.9408$.

4,5-Dibromopyrrole-2-carboxylic acid (4): light yellow powder; UV (MeOH) $\lambda_{\max }(\log \epsilon) 271(4.05) \mathrm{nm}$; ${ }^{1} \mathrm{H}$ NMR and ${ }^{13} \mathrm{C} N M R$ data same as reported in refs 3a,b; ESIMS (neg) m/z 266 (53), 268 (100), 270 (51).

Feeding Assays. A description of the feeding assay is given in the Supporting Information. Compounds $\mathbf{1}$ and $\mathbf{2}$ were tested at concentrations of $1,3,5$, and $10 \mathrm{mg} / \mathrm{mL}$. Three replicate assays were conducted at each concentration. For any individual assay, a treatment was considered deterrent if the number of pellets eaten was less than or equal to 6 ( $p<0.043$, Fisher exact test, one-tailed). ${ }^{11}$ The averaged values for the number of pellets eaten were (standard deviations in parentheses) $6.7(0.6), 4.3(0.6), 2.3(0.6)$, and $0.3(0.6)$ for 1 and 8.7 (0.6), $5.3(0.6), 3.3(0.6)$, and $0.7(0.6)$ for 2 . Compounds 3 and 4 were not tested again in this investigation because we have carried out this before. ${ }^{5 c}$

Acknowledgment. Financial support from the Deutsche Forschungsgemeinschaft (Ko $1314 / 3-1$ to $3-4$ ) is gratefully acknowledged. S.Z.'s work is contribution 665 from the Instituto de I nvestigaciones Marinas y Costeras-INVEMAR, and 184 from the graduate program in Marine Biology, Faculty of Sciences, Universidad Nacional de Colombia. F urthermore, we are grateful to Professor J oseph R. Pawlik (Department of Biological Sciences and Center for Marine Science, University of North Carolina, Wilmington) for giving M.A. and S.Z. the opportunity to participate in a scientific expedition to the Bahamas onboard the R/ V Seward J ohnson in J uly/August 2000, during which the sponge Agel as sventres was collected. The use of the research vessel Seward J ohnson was made possible through financial support from the U.S. National Science Foundation (OCE-9711255 to J . R. Pawlik). Wethank the captain and the crew of the R/ V Seward J ohnson for their cooperation and the government of the Bahamas for permission to perform research in their territorial waters. Funds for S.Z. to travel from Colombia to the U.S. to join the Bahamas cruise was provided by COLCIENCIAS through grant CO1101-09-129-95 to Carmenza Duque (Universidad Nacional de Colombia). We thank Ellen Lichte for performing HPLC analyses.

Supporting Information Available: A more detailed Experimental Section, including a detailed description of the Animal Material as well as some more information about the General Procedures and the Feeding Assays, is available free of charge via the Internet at http://pubs.acs.org.

\section{References and Notes}

(1) Lehnert, H.; van Soest, R. W. M. Beaufortia 1996, 46, 53-81.

(2) Assmann, M.; Lichte, E.; van Soest, R. W. M.; Köck, M. Org. Lett. 1999, 1, 455-457.

(3) (a) Forenza, S.; Minale, L.; Riccio, R.; Fattorusso, E. J . Chem. Soc., Chem. Commun. 1971, 1129-1130. (b) Garcia, E. E.; Benjamin, L E.; Fryer, R. I. J . Chem. Soc., Chem. Commun. 1973, 78-79. (c) Kobayashi, 」.; Ohizumi, Y.; Nakamura, H.; Hirata, Y. Experientia 1986, 42, 1176-1177. (d) Olofson, A.; Yakushijin, K.; Horne, D. A. J Org. Chem. 1998, 63, 5787-5790.

(4) (a) Pawlik, J. R.; Chanas, B.; Toonen, R. T.; Fenical, F. Mar. Ecol. Prog. Ser. 1995, 127, 183-194. (b) Chanas, B.; Pawlik, J. R. Mar Ecol. Prog. Ser. 1995, 127, 195-211. (c) Chanas, B.; Pawlik, J . R. Oecol ogia 1996, 107, 225-231.

(5) (a) Chanas, B.; Pawlik, J. R.; Lindel, T.; Fenical, W. J . Exp. Mar Biol. Ecol. 1996, 208, 185-196. (b) Wilson, D. M.; Puyana, M.; Fenical, W.; Pawlik, J. R. J . Chem. Ecol. 1999, 25, 2811-2823. (c) Assmann M.; Lichte, E.; Pawlik, J. R.; Köck, M. Mar. Ecol. Prog. Ser. 2000, 207, 255-262. (d) Assmann, M.; van Soest, R. W. M.; Köck, M. J. Nat. Prod. 2001, 64, 1345-1347.

(6) Pawlik, J. R.; Burch, M. T.; Fenical, W. J . Exp. Mar. Biol. Ecol. 1987 $108,55-66$

(7) Lindel, T.; Hoffmann, H.; Hochgürtel, M.; Pawlik, J . R. J . Chem. Ecol 2000, 26, 1477-1496.

(8) Wiedenmayer, F. Shallow-water sponges of the western Bahamas: Birkhäuser Verlag: Basel, Stuttgart, 1977.

(9) Zea, S. Esponjas del Caribe colombiano; Editorial Catálogo Científico: Bogotá, 1987.

(10) Alcolado, P. M. Poeyana 1984, 271, 1-22.

(11) Zar, J. H. Biostatistical Analysis, 4th ed.; Prentice Hall: Upper Saddle River, NJ , 1999.

NP010350E 


\section{Supporting Information}

\section{Experimental Section}

General Procedure. For extraction solvents were distilled prior to use, and gradient grade solvents were used for chromatographic applications. Fractions containing brominated metabolites were collected and monitored by TLC on pre-coated silica gel $60 \mathrm{~F}_{254}$ plates (Merck) using a mixture of $\mathrm{CHCl}_{3} / \mathrm{MeOH} / \mathrm{NH}_{3 \mathrm{aq}}(40: 20: 1)$ as solvent system and detected by their UV absorbance at 254 or $366 \mathrm{~nm}$. Thin-layer chromatography (TLC) was performed on pre-coated Si gel plates (Merck).

For HPLC analysis, samples were injected into a JASCO HPLC system equipped with a MD-910 photodiode-array detector. Routine detection was at $280 \mathrm{~nm}$. HPLC separation columns (analytical: $4.6 \times 250 \mathrm{~mm}, 5 \mu \mathrm{m}$; preparative: $16 \times 250 \mathrm{~mm}, 7 \mu \mathrm{m}$ ) were pre-filled with Kromasil $\mathrm{RP}_{18}(\mathrm{Knauer} \mathrm{GmbH})$. The following gradient was used for preparative HPLC analysis: $5 \min \mathrm{A}, 35 \mathrm{~min} 35 \% \mathrm{~B}$; A: $10 \% \mathrm{MeCN} / \mathrm{H}_{2} \mathrm{O}+0.1 \% \mathrm{TFA}, \mathrm{B}: \mathrm{MeCN}+0.1 \%$ TFA. Analytical HPLC was achieved by applying a linear gradient from $20-60 \% \mathrm{MeCN} / \mathrm{H}_{2} \mathrm{O}+$ $0.1 \%$ TFA in $40 \mathrm{~min}$. Fractions containing purified bromopyrrole alkaloids were combined on the basis of analytical HPLC.

The ${ }^{1} \mathrm{H},{ }^{13} \mathrm{C}-\mathrm{HMBC}$ experiment was acquired with 4096 data points in $\mathrm{F}_{2}, 256$ increments and 4 acquisitions. The delay for evolution of the heteronuclear long range couplings was set to $80 \mathrm{~ms}$ and the relaxation delay to $2.0 \mathrm{~s}$. The ${ }^{1} \mathrm{H},{ }^{15} \mathrm{~N}-\mathrm{HMBC}$ experiment was acquired with 8192 data points in $F_{2}, 64$ increments and 16 acquisitions. The delay for evolution of the heteronuclear long range couplings was set to $120 \mathrm{~ms}$ and the relaxation delay to $2.0 \mathrm{~s}$. The pulse programs were used from the Bruker library.

Animal Material. The specimen consists of a $15-22 \mathrm{~cm}$ in diameter cluster of bright orange, repent to erect, finger-shaped branches, each up to $2 \mathrm{~cm}$ in diameter, arising from a partly buried mass attached irregularly to corals and coral rubble; only the top few $\mathrm{cm}$ of the branches are seen by the diver. The surface is even, riddled with rounded to elongated holes, most of them roofed by a parchment-like membrane, and a few fully open, all 1-7 mm in diameter. On top of branches, the surface is a little rough, and there may be 1-2 roundish to elongated-contorted holes. The brighter color occurs near the top of branches; the nonexposed areas are cream; the interior tissue is orange; upon fixation in ethanol, it exudes an orange, opaque ink. The consistency is easily compressible, elastic, difficult to tear. The interior is extremely cavernous, with numerous roundish, interwoven tunnels, 3-6 mm in diameter, leaving relatively thin, 0.5-6 mm, walls of solid tissue. The skeleton consists of 
primary fibers ascending sinuously and branching irregularly, 28-120 $\mu \mathrm{m}$ in diameter, separated $70-400 \mu \mathrm{m}$, cored with 1 to 5 spicules in an irregularly plumose fashion; their sinuous ascent make them look short in thick sections under the microscope; they have echinating spicules here and there. Ascending fibers are interconnected by relatively long, uncored secondary fibers, 24-57 $\mu \mathrm{m}$ in diameter, which run more or less parallel to each other and to the surface. In between ascending primary and interconnecting secondary fibers, there is an irregular tri-dimensional network of fibers, forming rounded meshes $60-190 \mu \mathrm{m}$ in diameter. The dermis is supported by spicule brushes of the ascending primary fibers and by the tangentially placed, interconnecting secondary fibers, whose echinating spicules tend to pierce it. Spicules are acanthostyles, slender, relatively thin, showing a wide axial canal, with 9-18 whorls of 1-4 spines each; spines are slightly curved towards the head of the style and, although they are short $(<2.9 \mu \mathrm{m})$, they look high due to the thinness of the spicules. When compared with those of other species, acanthostyles of $A$. sventres usually are distinguished by having the head with a few spines, and several whorls with just 1 or 2 spines; although the distance between whorls is usually regular, sometimes there is a single spine in between whorls that obscure the pattern. There are many developmental stages of spicules without spines, showing just an engrossed ring where the whorls of spines will appear. Dimensions (length by width, min-mean-max, $\mathrm{n}=25$ spicules): $30-115.5-190 \mu \mathrm{m}$ by $2.3-4.6-6.2 \mu \mathrm{m}$.

Feeding Assays. Purified compounds were dissolved in a minimal volume of $\mathrm{MeOH}$ and mixed with $1 \mathrm{~mL}$ of alginate-based food matrix ${ }^{1}$ until all organic and water-soluble components were distributed uniformly throughout the paste. The alginate food matrix was then dispensed with a $1 \mathrm{~mL}$ syringe into a $0.25 \mathrm{M}$ calcium chloride solution forming a strand that was allowed to harden for $2 \mathrm{~min}$. The hardened strand was rinsed with filtered seawater and cut into $3 \mathrm{~mm}$ pellets with a scalpel. Control pellets were prepared identically but without the addition of natural compounds. Feeding assays were performed with fish (1 terminal phase and 2 females in each of 10 compartments) in aquaria onboard the $R / V$ Seward Johnson using a common omnivorous reef fish, the bluehead wrasse Thalassoma bifasciatum. Rationale for the choice of this assay fish and an explanation of the methods for scoring the assay and the statistical analysis is well described in ref. 2. Each replicate assay was performed on a separate group of fish.

\section{References}

(1) Pawlik, J. R.; Burch, M. T.; Fenical, W. J. Exp. Mar. Biol. Ecol. 1987, 108, 55-66.

(2) Pawlik, J. R.; Chanas, B.; Toonen, R. T.; Fenical, F. Mar. Ecol. Prog. Ser. 1995, 127, 183194. 